\title{
Traditional Game ‘Engklek’ and Young Children's Gross Motor Ability
}

\author{
Rachma Hasibuan \\ Dept. of Early Childhood Education \\ Universitas Negeri Surabaya, UNESA \\ Surabaya, Indonesia \\ rachmahasibuan@unesa.ac.id.
}

\author{
Miftakhul Jannah \\ Dept. of Psychology \\ Universitas Negeri Surabaya, UNESA \\ Surabaya, Indonesia \\ miftakhuljannah@unesa.ac.id
}

\begin{abstract}
This research aims to look at the influence of the traditional game 'Engklek' on the ability of the early children's gross motor. The hypothesis of this research is that there is an influence of the game to the children's gross motor ability. The method used in this research is the experimental method through one group pre test and post test design. The subjects of this research totalled 8 children, 3 girls and 5 boy (5-6 year old). The instrument of this research is Behavior Analytical Rating Scale (BARS) motor ability test from Bruininks and Bruininks. The results shows an increase as seen from the acquisition of an average yield of 31.5 at the pretest (low) becomes 58.5 (good) at the posttest. Analysis of the data used in this research is the Wilcoxon test. Wilcoxon test analysis result obtained value of Sig. $=0.011,(p<0.05)$ that means there is the influence of the traditional game of Engklek on gross motor ability of early children. The traditional game 'Englek' is effective to increasing the gross motor ability of early children. Increasing gross motor abily in this research caused by children's good physical strength since 'Engklek, included gross motor activity such as jumping and throwing. Besides, happiness and social value exist while playing that the kids do not feel when they do kind of burden activities.
\end{abstract}

Keywords : engklek; gross motor ability; early children

\section{INTRODUCTION}

Early childhood are very important times for the life of human. At this time the children begin to recognize the school. Children are also in the early age group, age exploring, age asking, creative age, and age of play. Learning for early childhood is done through fun atmosphere with play activities. The fun atmosphere that kids get when they play activities, for children to unconsciously learn without pressure, for motor development, cognitive, social emotional, language, etc.

Gross motor is body movement that used big muscles or most or all body limbs that are influenced by the children maturities such as abilities of sitting, kicking, running, walking up and down stairs and so on. Whereas fine motor is the movement that uses smooth muscles or partly certain body limbs, that are influenced by chances for learning and practicing such as the abilities of moving objects from hands, arranging blocks, scribbling, cutting, writing and so on. Both abilities are very important so that children can develop optimally [1]. Children motor ability roles are assumed as very central for supporting their life. Motor development especially gross motor is one of very important factors Hurlock [2].

The processes of smoothing children motor skills continue doing various physical activities that sometimes characterize as informal in game or play forms. Besides that, children also participate themselves in formal sport game activities such as swimming, gymnastics [3]. Motor development is different in levels in every individual. The children of four years can use scissors easily whereas the others temporarily may be able to use after five or six years old. Certain children may be able to jump and catch balls whreas the others may be only able to catch big balls or roll around. Similarly environmental stimulation, nutritional status, races and genetics have important influences in motor development (Shaffer et al., 2005).

Study about gross motor ability especially in school environment and playing environment with friends of the same age is still quite rare to research. More deeply Morrison revealed that motor development is children learning order that emphasizes in body movement, in which the movement plays important roles for children life especially related to attitudes and their social life [5].

Gross motor development problems in each kindergarten are quite different. Gross motor developmental patterns of one child and others are different, the case can be seen from learning activities and gross motor indicator achievements. Partly children are still seen as less skillful to do body movement in coordination for practising flexibility, stability, and agility. The case is seen from activities of playing the catwalk, playing climbing, running with patterns and obstacles, throwing a target, and other games, in which there are partly children who can do well by short times, whereas partly children are still less skillful in completing the games. Motor development problems are also seen from children abilities in imitating movements especially in dance and gymnastics movements, partly children are still clumpsy for moving their body limbs even partly children are very late in following their teacher movements and they cannot explore flexibility and agility [6]. 
'Engklek' is traditional game was famous. This game is done through fun atmosphere. The activities of games are walk, jump with one leg or two legs (Mulyani, 2013). Rule of engklek, every player must jump with one or two legs depend on clue. Some time with one leg if this media show picture of one foot. The same rule for two legs.

In 'Engklek: need player using physical activity during play this game. Rolling player periodically play and lead this game. Mostly body must movement while lead this game [7]. Based on observational results at At Taqwa Kindergarten, Surabaya, it is known that several problems related to children's gross motoric abilities. Children tend to be quite, they don't like to jump, egoists and they do not want to relent when playing ones. One of learning methods that emphasizes in children's gross motoric ability is traditional playing.

The purpose of this research is for analyzing increasing gross motor ability trough Engklel, traditional game in children of At Taqwa Kindergarten Surabaya.

\section{METHODS}

This research used quantitative experimental research to find the influence of a treatment or manipulation of other variables under controlled conditions conducted by researchers [8]. This research belongs to quasi experimental research, of which the entire process required are planning and conducting experimental research without control group [8]. The design of this research was one group pretest and posttest design.

The subjects of this research totalled 8 children, 3 girls and 5 boy (5-6 year old, mean 5,5 year old) from At Taqwa Kindergarten, Surabaya, East Java. Data collection techniques is the most important step in the research, because the main goal of research is to get the data, [9]. Based on the information, the data were collected using Behaviour Analytical Rating Scale (BARS) motor ability test dari Bruininks and Bruininks. Analysis of the data using Wilcoxon Signed Rank Test.

\section{RESULT AND DISCUSSION}

The results showed that before treatment was given, the gross motor ability was still low, which can be seen from the low average pretest results. Meanwhile, after giving treatment using 'engklek', posttest result average is good. The result can be seen from the following table:

\section{Table1}

Descriptive Analysis

\begin{tabular}{|c|l|c|l|c|l|c|}
\hline No & Subject & Pretest & Category & Posttest & Category & $\begin{array}{c}\text { Gain } \\
\text { Score }\end{array}$ \\
\hline 1 & AA & 35 & Medium & 54 & Good & 19 \\
\hline 2 & AR & 30 & Low & 59 & Good & 29 \\
\hline 3 & BA & 29 & Low & 54 & Good & 25 \\
\hline 4 & FF & 30 & Low & 57 & Good & 27 \\
\hline 5 & MD & 30 & Low & 57 & Good & 27 \\
\hline 6 & MY & 33 & Medium & 67 & Very good & 34 \\
\hline 7 & PE & 32 & Low & 59 & Good & 27 \\
\hline 8 & RE & 33 & Medium & 61 & Good & 28 \\
\hline \multicolumn{2}{|c|}{ Average } & 31,5 & Low & 58,5 & Good & 27 \\
\hline
\end{tabular}

The result calculation of different pretest and posttest this research is done by using Wilcoxon Signed Ranking Test, obtained value of Sig. $=0.011,(p<0.05)$, so it can be concluded that there is influence of the traditional game of Engklek on gross motor ability of early children.

The discussion of traditional game "Engklek" influences early children's gross motor ability in Kindergarten was explained as follows:

1. There was influence of traditional game "Engklek" influences early children's gross motor ability in At Taqwa Kindergarten in Surabaya. The results of the pretest showed that there was gain score of gross motor ability were positive score (27). The indicators of improving Children's gross motor ability development. The results was in line with research by Lucht, Domagk and Mohring [3]. Hopscotch (Germany 'engklek' ) have good impact to increasing gross motor ability in learning process. In 'engklek' children must walk, jump, and throw, so that they can movement with their big muscle. In other words, their activity using physical activities.

In the Engklek game, the children could train to jump to square to square with detail. It means children train to movement their body to other place. This activity need gross motor skill ability. Therefore, it was concluded that children's gross motor ability increase through 'engklek' traditional game.

2. Result of research showed, average pretest in gross motor ability were low score. It mean, children have low ability of gross motor. But in posttest, average score is good. It mean, children have good ability of gross motor. In other world, 'engklel' traditional game increasing children's gross motor ability.

The number of children's delayed ability can be caused by the lack of fulfillment needs in children, including the need to play. Because playing was not just a filler of leisure time, but also helped to prepare children's brains for the challenges faced [6]. Therefore, one way to improve the gross motor ability of preschoolers was by playing.

The gross motor ability of kindergarten children influenced by ripening (maturation) and learning factors [10]. Maturation factor related to the intellectual development and the development of the endocrine glands, while the factors of learning itself consists of several methods, the trial and error learning (learning by trial and error), learning by imitation (learning by imitation), learning by identification (learning by means of identification), air conditioning (learn by association), and training (learning with the guidance and supervision).

Most of the respondents who had low gross motor ability during the pre-test. At posttest, respondents 
who had a good gross motor ability. This was consistent with the Samsudin, stating that children of kindergarten age can hit, bite, or push as a way to improve their ability are $80 \%$ of them are using physical activities [11]. Children's gross motor ability of 5 to 6 years old is very rapid. In these ages, children begin to develop new skills and improve the skills that they have had. This ability is also showed by good stability in climbing the beam/plank board, jumping up and down several stairs, jumping various objects, jumping well, jumping rope, climbing, swimming movement coordination, and even driving two-wheel bicycle.

\section{CONCLUSION}

Based on the data interpretation results and the discussions that have been put forward before, it can be explained that gross motor ability can increase by engklek the traditional game. The game make children happy, have fun to move their body. Children train gross movement, improve abilities of managing, controlling body movement and coordination, and also improve body skills and the ways of living healthy, so it can support healthy, strong, and skillful physical growth.

So, the suggestions in this research are as follows: (1) It is hoped so that engklek, traditional game, can become alternative play for children in kindergarten in millennial century. Educating children by giving attention to children's movement with fun atmosphere, giving challenge for children to move their body. Support children feel motivated for doing the physical activity through engklek, traditional game, things so it can help their gross motor ability.

\section{References}

[1] Burrows, J. E., Keats, M. R., Kolen, A. M, (2014).“Contributions of After School Programs to the Development of Fundamental Movement Skills in Children", vol. 07, no. 03. Jurnal Psikologi.

[2] Hurlock, E. B, (2008). Psikologi Perkembangan Suatu Pendekatan Sepanjang Hidup. Alih bahasa: Istiwidayanti \& Soedjarwo. Jakarta: Penerbit Erlangga.

[3] Lucht, M \& Domagk, S. ,Mohring, M,(2014) "Exer-Learning Games: Transferring Hopscotch from the School yard to the Classroom. Germany: Fraunhofer Institute for Digital Media Technology IDMT", Jurnal Psikologi.

[4] Shaffer, D., I. Schonfeld, P.A. O'Connor, C. Stokman, P. Trautman, S. Shafer and S. Ng.,(2005) Neurological soft signs: Their relationship to psychiatric disorder and intelligence in childhood and adolescence. Arch. General Psychiatry, 42: 342-35

[5] Morrison, G.S. (2000), Fundamentals of Early Childhood Education. 2nd Edn., Merrill Prentice Hall, Inc., USA, 2000.

[6] Ardiyanto, A dan Sukoco, P, (2014) "Developing a Teaching Model of Traditional Games to Increase Gross Motor of Intellectual Developmental Disorder Children," vol. 2. No. 02.

[7] Fad, A.,(2014). Kumpulan Permainan Anak Tradisional Indonesia. Jakarta: Penerbit Cerdas Interaktif (Penebar Swadaya Grup).

[8] Jannah, M., (2016) Psikologi Eksperimen: Sebuah Pengantar, Surabaya: Unesa University Press.

[9] Sugiono, (2012). Metode Penelitian Kuantitatif, Kualitatif, dan R \&D., Bandung: Alfabeta

[10] Santrock, J. W, (2013). Perkembangan Anak, edisi ketujuh, jilid dua. Alih bahasa: Mila Rachmawati \& Anna Kuswati. Jakarta: PT. Gelora Aksara Pratama.
[11] Samsudin, (2005). Pengembangan Motorik di Taman Kanak-kanak. Jakarta: Fakultas Ilmu Keolahragaan Universitas Negeri Jakarta. 